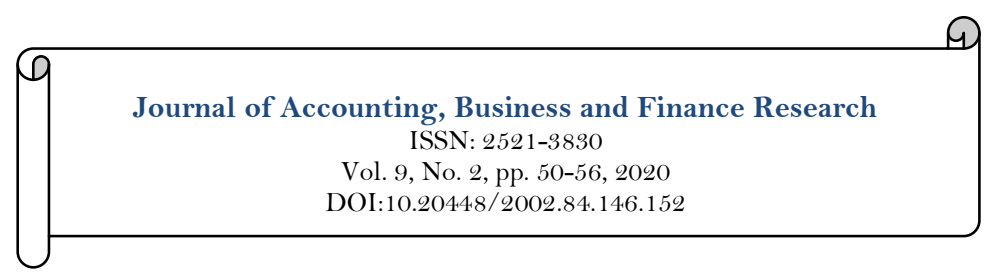

\title{
Capital Structure and Firm's Profitability: Evidence From Listed Consumer Goods Sector in
} Nigeria

\author{
Udobi-Owoloja, P. I. ${ }^{\text {* }}$ \\ Gbajumo-Sheriff, M.A. ${ }^{2}$ \\ Umoru, B. ${ }^{3}$ \\ Babatunde, S.A ${ }^{4}$ \\ Ilimezekhe, $\mathrm{D}^{5}$ \\ 1,2,3,4,5 Faculty of Management Sciences, University of Lagos, Akoka, Lagos, Nigeria. \\ ${ }^{2}$ Email: udobiphil@yahoo.com
}

\begin{abstract}
This study investigated the impact of capital structure on profitability of consumer goods firms in Nigerian for a period of eight years (2011-2018). Data of ten (10) randomly selected listed firms of the Nigeria Stock Exchange were derived from the firms' published financial reports for the period covered. The panel regression results revealed that Debt to Asset Ratio(DAR) is positively significant on Return On Asset(ROA) (Proxy for profitability), while other proxies of capital structure shows that Debt to Equity(DER), Liquidity Ratio(LIQ), are not statistically significant, Short Term Debt to Total Asset Ratio (SDTA) shows a negative connection, Firm Size (FS) has a weak correlation with profit and Long Term Debt to Total Asset Ratio (LDTA) do not influence firms' profitability of the consumer goods sector of Nigeria economy. In conclusion, capital structure influences the profitability of consumer goods sector of Nigerian Stock Exchange. It was recommended that firms in that sector should leverage on debt financing to boost their earnings as interest payment on debt is tax deductible.
\end{abstract}

\author{
Keywords: \\ Capital structure \\ Debt \\ Equity \\ Profitability \\ Consumer goods \\ Economy. \\ JEL Classification: \\ G32.
}

Licensed:

This work is licensed under a

Creative Commons Attribution 4.0

License.

Publisher:

Scientific Publishing Institute

Received: 25 February 2020 Revised: 30 March 2020

Accepted: 7 April 2020

Published: 29 April 2020

Funding: This study received no specific financial support.

Competing Interests: The authors declare that they have no competing interests

Acknowledgement: Authors acknowledge their colleagues who helped in proof reading and editing this paper.

\section{Introduction}

One of the motivating factors in establishing a firm is to maximize profit which is paramount to the firms' going concern. Survivability of an organization depends on the profit just as the profits earned by investors relies upon the firm long-term profit (Agha, 2015). Profit has various meaning to various groups. It could be defined as gains made after deductions of all expenses incurred in generating the profit. Profitability estimates the degree of perfection of an enterprise in employing assets to generate gains for the company and for investors' esteem (Agha, 2015). Profitability is conceptualized as a ratio among gains and various kinds of used assets. The more the rate of gains, the more the rate of profitability. The central focus of budgetary examination is to exhibit enterprise ability to create profit as far as overall income which reveals the estimates 
of profit the enterprise delivers on the business transaction at the various phases. Hifza (2011) state that the profitability and productivity are important factor of a firm's performance. Be that as it may, an organizations productivity or the capacity of a firm to make profit is subject to numerous elements that has been utilized in the administration of the business.

A major component of determining firm's performance among others is capital structure. Capital structure is described as the manner in which firms combines the numerous sources of funding in the firm's operational activities there by giving an insight on the riskiness of the firms' operations. Rahman, Sarker, and Uddin (2019) defined capital structure as the mix in which firms' management chose to combine debt, equity or both in the firm's operation so as to maximize shareholders' wealth. Capital Structure incorporates equity capital, profit retained, long and short term borrowings, preferred capital, debentures, current and non-current liabilities of the organization. An organization's decision on the structure of capital is a major decision the firm must take in the course of the business life time. It is seen as a process whereby enterprise finance their activities and expansion by employing their financial resources in the form of asset. Capital structure connotes outstanding debt obligation and equity that empowers enterprise to comprehend the kind of funding it should employ to finance it business.

Rosario and Chavali (2019) buttress that capital structure decision is a key determinants of a firm's profit. Dang, Bui, and Nguyen (2019) added that a common tool in improving firm's profit is the use of debt over equity. Wasfi and Haneen (2016) argued that in making capital structure decision, a trade-off between risk and return is also being made, and it is important to find the equilibrium between the two (Risk and return) (Saputra, Achsani, \& Anggraeni, 2015). The balancing of the risk and return in capital structure is termed optimal capital structure. This is one of the most vital task of firm's management in funding (Rosario \& Chavali, 2019).

Optimum capital structure is the point at which debt and equity ratios are at equilibrium that can make a firm to maximize profits and minimize capital cost (Dang et al., 2019). It is also a mixture of loan and equity in funding to minimize the firm's debt servicing. Dawood, Moustafa, and El-Hennawi (2011) state that business firms can raise funds from equity or debt to boost its business, however these sources of funds have their implications. Dang et al. (2019) added that the choice of funding between equity and debt in the quest of maximizing shareholders' wealth has its advantages and disadvantages when employed. If excessive amount of debt is employed, its liabilities or associated high cost of debt may over stretch the firm's financial capability, while an excessive employment of equity, weakens proprietorship premium and it opens the organization to outside control.

Anarfo and Appiahene (2017) expressed their opinion on the implications of capital structure financing. The authors explained that there is a signalling effect attached to the choice of firms' capital structure. If a company adopts debt financing in its operations, it could signal management confidence on improved future earnings of the firm to its stakeholders. Likewise, if equity financing is employed through initial public offers at a reduced price when compared to the prevailing market rate, it could signal to its stakeholders that the current equity market price is overvalued. As a result, the ability, integrity and intention of the firm's management is questioned.

Capital structure theory was propounded by Modigliani and Miller (1958). This capital structure irrelevancy theory, argued that there is no relationship between capital structure and firm's profit. In other words, shareholders are indifferent about firm capital structure reason being that the firm's value do not change with changes in debt. This theory is made to function in a market where there are free entry and exit, no transaction cost, no asymmetry information, non-existence of taxes, rational behaviour of investors, Constant cash-flow, risk free interest rate, no bankruptcy cost, perfect and efficient market among other assumptions. Modigliani and Miller (1958) capital structure irrelevancy was debunked with its restrictive assumptions. However, Modigliani and Miller (1963) later suggested that firms should take advantage of tax shield when relying on debt capital to maximize firms' value. Debt becomes beneficial if firm's interest deduction and taxation are taken into consideration.

Capital structure has been a controversial topic, globally with contradictory findings. The effect of different variables as proxies for capital structure has been measured overtime and its influence on firms' performance. Previous studies have shown that capital structure has different influence on the business performance of various sectors of the economy. Findings of some studies that show positive significant correlation between debt and firms' profitability are Kbewar (2012); Rajendran and Nimalthasan (2013); Nirajini and Priya (2013); Goh, Hall, and Rosenthal (2016). Some of the studies in support of equity over debt financing are Muhammad, Shah, and Ul Islam (2014); Vătavu (2015); Sabin and Miras (2015); Nassar (2016) while others who recorded no connection between capital structure and profitability of firms are Prahalathan and Ranjani (2011); Babalola (2012); Muritala (2012); Maina and Kondongo (2013); and Sabin and Miras (2015).

Iwarere and Akinleye (2010) observed that an enormous part of these examinations of the correlations of capital structure and profit revolves around firms in the financial sector of the nation. There has been no universal consensus on the relationship between capital structure and profitability of firms. Thus, it is 
paramount to investigate the association existing in structure of capital and profitability of listed consumer goods firms in Nigeria.

\section{Literature Review}

Over time, other theories have emanated from MM theory and other researchers has built on this theory. Different variables had been introduced, tested with various contradictory end results. Studies on capital structure has been subjected to critical analysis. Since the performance of firms that produce consumer products are basic to the progression of any economy, a couple of capital structure examinations have been directed towards factors of capital structure that have effect of on firm's earnings.

Akinyomi (2013) surveyed the relationship between capital structure and firm's performance of Nigerian manufacturing industry within periods 2007-2011. Data were extracted from 3 randomly selected food and beverages organizations of the manufacturing sector. The study used ROE and ROA as dependent variables, long term debt to capital, Debt to equity, Short term debt to total debt were proxies for capital structures while firm's age was used as control variable. The findings showed that there is a connection between debt and firms' earnings. The study concluded that financial leverage should be considered in determining firm's survival. Mubeen and Akhtar (2014) study also showed that capital structure impacts financial performance of 155 firms in Pakistan during the period of study (2006-2011).

Vătavu (2015) measured the impact of capital structure of 196 firms in Romania for period from 2003 to 2010. The study demonstrated that total debt and short term debt do not affect firms' performance, rather equity capital has a positive effect on firm's performance of Bucharest Stock Exchange. Finding showed that shareholders' funds brings about better performance. They further stated that Romanian firms rarely employ debt in their businesses except when in dare need of funds.

Saputra et al. (2015) conducted a research on the effect of capital structure on Indonesia firm's performance for a duration of five years $(2009-2013)$. Secondary data were extracted from end of year report of fifty-five (55) firms of the financial sector of Indonesia stock market. The result from the regression analysis showed that debt has a positive impact on the financial sector firm's performance in Indonesia. Wasfi and Haneen (2016) investigated the existence of the correlation between capital structure and stock returns of quoted industrial firms of Amman Stock Market for a duration of eight (8) years (2007 - 2014). Regression model was used to analyse data derived from financial statements of selected firms. Results showed that capital structure has a direct relationship with industrial firms on Amman Stock market. They stated that the findings influence the managerial decision when formulating its capital structure in its long term investments.

Warrad, Al-Nimer, and Al-Omari (2016) tried to see if liquidity through risk proportion has significant consequence on financial institution's profitability in Jordan. The investigation utilized 2005-2011 annual reports of 15 Jordan's financial intermediaries of Amman Stock Exchange. Investigation revealed an accurate performance of quick ratio on return on asset (ROA). That denotes productivity through return on asset (ROA) of banks in Jordanian is really impacted by liquidity. Nassar (2016) examined the impact of capital structure on 136 companies of the industrial sector of Istanbul Stock Exchange in Turkey for periods within 2005 - 2012. The study showed that capital structure significantly but negatively impacts the industrial sector firm in Turkey.

Isik, Unal, and Unal (2017) explored 112 public manufacturing firms in Borsa, Istanbul. Nine years' data were extracted from Finnet database $(2005$ - 2013). Its aim was to measure the strength of firm size on the profit of manufacturing firms quoted on Istanbul Stock Exchange for the period covered. Dynamic panel data approach (two-advance framework GMM estimator) was utilized considering potential indigeneity of firmlevel factors was utilized to measure the impact of firm size on firm profitability. The study found that there is a direct significant relationship between firm size and productivity of Manufacturing firms in Turkey.

Madushanka and Jathurika (2018) examined the effect of capital structure on productivity of 15 sampled listed manufacturing firms of Colombo stock market for a duration of 5 years $(2012-2016)$. The result of the regression analysis showed that liquidity ratios has a positive and significant influence on the manufacturing firms' profitability. Uremadu and Onyekachi (2018) extract data from the annual report of 4 consumer goods corporate firms listed on NSE within periods 2002 - 2016. The multiple regression results revealed that long term debt to total assets ratio and the total debt to equity capital ratio are both negative and insignificant. In conclusion, Capital structure does not affect the financial performance of corporate companies in the consumer goods sector in Nigeria.

Rahman et al. (2019) investigated the influence of capital structure on the profit of ten selected manufacturing firms in Bangladesh over five years' period. The results showed that debt and equity has a positive impact on the firms' performance while debt to equity ratio has a significant negative impact on the performance of the selected manufacturing firms in Dhaka Stock Exchange, Bangladesh. Rosario and Chavali (2019) measured the influence of capital structure on the profitability of twenty-two (22) hotels in India within 2006-2017 periods. The regression analysis showed a positive impact of debt on hotels' performance in India.

Dang et al. (2019) measured the relationship between capital structure and the performance of sixty-one (61) food and Beverages firms in Vietnam for periods within 2000-2017. ROA, EPS and ROE (proxies for firm's performance), debt ratio, short term debt and long term debt ratio. The outcomes showed that debt ratio 
affects ROE and EPS but it does not affect ROA. It means that firm financed with high level of debt performs better when measured by ROE but performs poorly when measured by ROA. The study concluded that debt significantly impact food and beverages firms' performance in Vietnam. Singh and Bagga (2019) conducted a research on capital structure and profitability of quoted India firms within 2008-2017. Its findings also support the relevancy of capital structure on firm's profits.

\section{Research Methods}

This study tested for the impact of capital structure on firm's profitability of ten (10) randomly sampled firms of the consumer goods sector of Nigeria for a duration of eight years (2011 -2018). Data were derived from the financial report of firms with readily available and accessible data for the period covered.

\subsection{Model Specification}

This study formulated the following model to be used in the investigation. The model equation is expressed as follows:

$$
R O A=f(D A R, D E R, L I Q, S D T A, L D T A, F S)
$$

Equation 1 is indicated above in its functional form. It shows the relationship between the dependent variable(ROA) and the control variables which are proxies for capital structure.

This Equation 1 can be transformed into a linear function thus:

$$
R O A=\beta 0+\beta 1 D A R i t+\beta 2 D E R \text { it } i+\beta 3 L I Q i t+\beta 4 \text { SDTAit }+\beta 5 \text { LDTAit }+\beta 6 \text { FSit } i+U
$$

Equation 2 shows the linear regression model of the dependent variable(ROA) and the independent variables.

Where:

ROA = Return on Assets.

$\beta_{0}=$ Constant.

$\beta_{1}, \ldots \ldots \beta_{6}$, = Regression coefficients.

DAR $=$ Debt to Asset Ratio.

DER $=$ Debt to Equity Ratio.

LIQ = Liquidity Ratio.

SDTA $=$ Short Term Debts to Asset.

LDTA $=$ Long Term Debts to Asset.

FS = Firm Size (which is taken as the Natural Logarithm of total assets of the firms).

$\mathrm{U}=$ Error term used in the model.

\section{Analyses and Results Presentation}

4.1. Descriptive Statistics of Variables

The result represents statistical analysis of variables utilized in the investigation as expressed in the model specification.

\begin{tabular}{l|c|c|c|c|c|c|c}
\multicolumn{9}{c}{ Table-1. Descriptive statistics of variables. } \\
\hline \multicolumn{1}{c|}{ Statistics } & ROA & DAR & DER & LIQ & SDTA & LDTA & FS \\
\hline Mean & 0.134202 & 0.611749 & 0.613949 & 1.721963 & 0.448421 & 0.185805 & 19.36874 \\
\hline Median & 0.056395 & 0.607570 & 0.492822 & 0.872431 & 0.437957 & 0.156940 & 18.69328 \\
\hline Maximum & 1.351369 & 1.231111 & 5.490866 & 44.05521 & 1.011838 & 0.705947 & 25.60488 \\
\hline Minimum & -0.25727 & 0.011205 & -0.809757 & 0.380527 & 0.008759 & 0.011205 & 16.79483 \\
\hline Std. Dev. & 0.264476 & 0.206779 & 0.826990 & 4.892329 & 0.197341 & 0.125791 & 2.274242 \\
\hline Skewness & 3.259824 & -0.006409 & 3.995742 & 8.269994 & 0.553681 & 1.528617 & 1.610066 \\
\hline Kurtosis & 13.65771 & 4.600374 & 22.05096 & 71.89082 & 3.984788 & 6.226899 & 4.475019 \\
\hline Jarque-Bera & 520.3087 & 8.537875 & 1422.677 & 16731.72 & 7.320185 & 65.86518 & 41.81642 \\
\hline Probability & 0.000000 & 0.013997 & 0.000000 & 0.000000 & 0.025730 & 0.000000 & 0.000000 \\
\hline Sum & 10.73615 & 48.93992 & 49.11596 & 137.7571 & 35.87366 & 14.86443 & 1549.499 \\
\hline Sum Sq. Dev. & 5.525838 & 3.377849 & 54.02906 & 1890.856 & 3.076549 & 1.250056 & 408.6020 \\
\hline Observations & 80 & 80 & 80 & 80 & 80 & 80 & 80 \\
\hline
\end{tabular}

Table 1 shows the descriptive value of different variable, the maximum and minimum value in the table shows the highest and lowest value of the dataset from the 2011 -2018 period. Regarding the degree of unpredictability estimated by standard deviation, the outcomes shows that the estimation of the LIQ and FS panel dataset for the 10 selected quoted companies tends to fluctuate after some time. Thus, it shows that every one of the factors aside from DAR skewed away from the ordinary appropriation point.

Table 2 shows the information obtained from the result of the Levin, Lin and Chu panel test of stationarity to confirm the stationarity of the data. The outcome acquired shows that every one of the factors 
in the model was stationary at level. In the after effect of the board acquired from above, it is accepted that there is no time pattern. It was discovered that the invalid theory of a board unit root is dismissed in all arrangement from the start contrast. The data on the table uncovers that there is solid exact proof that all the board dataset is coordinated of requests one at their levels.

\begin{tabular}{c|c|c|c}
\multicolumn{4}{c}{ Table-2. Panel unit root test. } \\
\hline Variable & Statistic & Prob. & Order of integration \\
\hline ROA & -3.4985 & $0.0002^{* * *}$ & $\mathrm{I}(0)$ \\
\hline DAR & -1.63150 & $0.0514^{* *}$ & $\mathrm{I}(0)$ \\
\hline DER & 63.5227 & $0.0008^{* * *}$ & $\mathrm{I}(0)$ \\
\hline LIQ & -819.439 & $0.0000^{* * *}$ & $\mathrm{I}(0)$ \\
\hline SDTA & -6.29845 & $0.0000^{* * *}$ & $\mathrm{I}(0)$ \\
\hline LDTA & -4.48735 & $0.0000^{* * *}$ & $\mathrm{I}(0)$ \\
\hline FS & -2.43590 & $0.0074^{* * *}$ & $\mathrm{I}(0)$ \\
\hline
\end{tabular}

Table-3. Pooled regression result.

\begin{tabular}{c|c|c|c|c|c|c}
\hline Variable & Coefficient & Std. Error & t-Statistic & Prob. & R-squared & $\mathbf{0 . 2 8 0 6 7 3}$ \\
\hline C & 0.016598 & 0.03369 & 0.492654 & 0.624 & Adjusted R-squared & 0.212165 \\
\hline DAR & 0.435267 & 0.146499 & 2.971134 & 0.0042 & F-statistic & 4.096968 \\
\hline DER & 0.02102 & 0.075611 & 0.277999 & 0.7819 & Prob(F-statistic) & 0.001562 \\
\hline LIQ & -0.013996 & 0.005099 & -2.74466 & 0.0079 & Durbin-Watson stat & 2.096743 \\
\hline SDTA & -0.751755 & 0.219841 & -3.419537 & 0.0011 & & \\
\hline LDTA & -0.198425 & 0.416073 & -0.476901 & 0.6351 & & \\
\hline FS & -0.013668 & 0.038666 & -0.353484 & 0.7249 & & \\
\hline
\end{tabular}

Table 3 reveals the pooled regression result to test the impact of the DAR, DER, LIQ, SDTA, LDTA and FS on profitability, measured by ROA. The result shows that only DAR, LIQ and SDTA are statistically significant. It was found that $28 \%$ of the variation in ROA can be explained by the explanatory variables. Result on the model shows that it is statistically significant $(\mathrm{F}=4.0970, \mathrm{p}(0.001)<0.05)$ and it is free from serial correlation (DW=2.0967). However, since the pooled regression model does not acknowledge the presence of heterogeneity it may not be consider appropriate for use.

Table-4. Fixed Effect regression result.

\begin{tabular}{c|c|c|c|c|c|c}
\hline Variable & Coefficient & Std. Error & t-Statistic & Prob. & R-squared & 0.313051 \\
\hline C & 0.016721 & 0.035607 & 0.469612 & 0.6405 & Adjusted R-squared & 0.122231 \\
\hline DAR & 0.445588 & 0.155884 & 2.858459 & 0.006 & F-statistic & 1.64056 \\
\hline DER & 0.02917 & 0.085331 & 0.341848 & 0.7338 & Prob(F-statistic) & 0.093384 \\
\hline LIQ & -0.013801 & 0.005387 & -2.561976 & 0.0132 & Durbin-Watson stat & 2.190125 \\
\hline SDTA & -0.816197 & 0.2386 & -3.420777 & 0.0012 & & \\
\hline LDTA & -0.190855 & 0.449829 & -0.424282 & 0.673 & & \\
\hline FS & -0.020902 & 0.044432 & -0.470431 & 0.6399 & & \\
\hline
\end{tabular}

Table 4 is the result of fixed effect regression on impact of the DAR, DER, LIQ, SDTA, LDTA and FS on the profitability, measured by ROA. The result shows that only DAR, LIQ and SDTA are statistically significant. The independent variables explain 31\% (R-squared 0.313051 ) of the variation in ROA and the model is statistically significant at the $10 \%$ significance level $(\mathrm{F}=1.6406, \mathrm{p}(0.093)<0.10)$ and it is free from serial correlation (DW=2.1901). To choose the appropriate model to use the study carried out a Hausman specification test.

Table-5. Correlated random effects - hausman test.

\begin{tabular}{c|c|c|c|c}
\hline \multicolumn{2}{c}{ Test Summary } & Chi-Sq. Statistic & Chi-Sq. d.f. & Prob. \\
\hline \multicolumn{2}{c|}{ Cross-section random } & $\mathbf{2 . 1 6 4 0 2 9}$ & $\mathbf{6}$ & $\mathbf{0 . 9 0 4}$ \\
\hline Variable & Fixed & Random & Var (Diff.) & Prob. \\
\hline DAR & 0.445588 & 0.435267 & 0.000388 & 0.6003 \\
\hline DER & 0.02917 & 0.02102 & 0.000912 & 0.7872 \\
\hline LIQ & -0.013801 & -0.013996 & 0 & 0.3712 \\
\hline SDTA & -0.816197 & -0.751755 & 0.003083 & 0.2458 \\
\hline LDTA & -0.190855 & -0.198425 & 0.009468 & 0.938 \\
\hline FS & -0.020902 & -0.013668 & 0.000308 & 0.6804 \\
\hline
\end{tabular}


The result on Table 5 reveals DAR has a statistically significant effect on profitability $(\mathrm{P}(0.0063)<0.05)$. The result also conforms to a priori expectation which hold that a rise in DAR causes an increment in ROA. By extension the result means that a one-point increase in DAR will result in a $0.44(\beta=0.435267)$ increment in profitability in the consumer goods sectors of the NSE.

\section{Conclusion and Recommendation}

This study focuses on capital structure and firm's profitability of the consumer goods sector listed on the NSE for duration of eight years. The study employed six proxies to represent capital structure and it was observed that Debt to Asset Ratio (DAR) is positively significant on firms in the consumer goods sector' profitability, while Debt to Equity Ratio (DER) and Liquidity Ratio (LIQ) are not statistically significant, Short Term Debt to Total Asset Ratio (SDTA) shows a negative connection, Long term Debt to Total Asset (LDTA) showed no significant relationship and Firm Size (FS) has a weak correlation with profit. The study confirmed that capital structure influence firm profitability of listed consumer goods firms in Nigeria during the period covered. It is therefore recommended that financial leverage should be employed by firms in the consumer goods sector to boost their earnings as interest payment on debt is tax deductible and for sustenance of future performance.

\section{References}

Agha, H. (2015). Determinents of capital structure of cement sector in pakistan. European Scientific Journal, 11(13), 353367.

Akinyomi, O. J. (2013). Effect of capital structure on firm performance: Evidence from Nigerian manufacturing industry. International Journal of Innovative Research and Studies, 2(9), $469-480$.

Anarfo, E. B., \& Appiahene, E. (2017). The impact of capital structure on banks profitability in Africa. Journal of Accounting and Finance, $17(3), 55-66$.

Babalola, Y. A. (2012). The impact of corporate social responsibility on firms' profitability in Nigeria. European Journal of Economics, Finance and administrative sciences, 45(1), 39-50.

Dang, Y. T. H., Bui, N. T. H., \& Nguyen, H. T. (2019). The impact of capital structure on firm performance: Empirical evidence from listed food and beverages companies in Vietnam. International Journal of Economics, Commerce and Management, 7(2), $567-577$.

Dawood, M., Moustafa, E., \& El-Hennawi, M. (2011). The determinants of capital structure in listed Egyptian corporations. Middle Eastern Finance and Economics, 9(1), 83-99.

Goh, J. X., Hall, J. A., \& Rosenthal, R. (2016). Mini meta-analysis of your own studies: Some arguments on why and a primer on how. Social and Personality Psychology Compass, 10(10), 535-549.Available at: https://doi.org/10.1111/spc3.12267.

Hifza, M. (2011). Determinants of insurance companies' profitability: An analysis of insurance sector of Pakistan. Academic Research International, 1(3), 9-19.

Isik, O., Unal, E. A., \& Unal, Y. (2017). The effect of firm size on profitability: evidence from Turkish manufacturing sector. Journal of Business Economics and Finance, 6(4), 301-308.

Iwarere, H., \& Akinleye, G. (2010). Capital structure determinants in the Nigerian banking industry: Financial managers' perspectives. Pakistan Journal of Social Sciences, 7(3), 205-213.Available at: https://doi.org/10.3923/pjssci.2010.205.213.

Kbewar, M. (2012). Capital structure and profitability: An empirical study using French panel data. MPRA Paper 42446.University Library of Munich.

Madushanka, K. I., \& Jathurika, M. (2018). The impact of liquidity ratios on profitability. International Research Journal of Advanced Engineering and Science, 3(4), 157-161.

Maina, L., \& Kondongo, O. (2013). Capital structure and financial performance in Kenya: Evidence from firms listed at Nairobi securities exchange. Paper presented at the Jomo Kenyatta University of Science and Technology Research Conference, Kenya.

Modigliani, F., \& Miller, M. H. (1958). The cost of capital, corporation finance and the theory of investment. The American Economic Review, 48(3), 261-297.

Modigliani, F., \& Miller, M. H. (1963). Corporate income taxes and cost of capital: A correction. The American economic reviere, 53(3), 433-443.

Mubeen, M., \& Akhtar, K. (2014). Impact of capital structure on firms financial performance and shareholders wealth: Textile sector of Pakistan. International Journal of Learning and Development, 4(2), 27-33.Available at: https://doi.org/10.5296/ijld.v4i2.5511.

Muhammad, H., Shah, B., \& Ul Islam, Z. (2014). The impact of capital structure on firm performance: Evidence from Pakistan. The Journal of Industrial Distribution and Business, 5(2), 13-20.Available at: https://doi.org/10.13106/jidb.2014.vol5.no2.13.

Muritala, T. A. (2012). An empirical analysis of capital structure on firms' performance in Nigeria. International Journal of Advances in Management and Economics, 1(5), 116-124.

Nassar, S. (2016). The impact of capital structure on financial performance of the firms: Evidence from Borsa Istanbul. Journal of Business and Finance Affairs, 5(2), 1-4.Available at: https://doi.org/10.4172/2167-0234.1000173.

Nirajini, A., \& Priya, K. (2013). Impact of capital structure on financial performance of the listed trading companies in Sri Lanka. International Journal of Scientific and Research Publications, 3(5), 1-9. 
Prahalathan, B., \& Ranjani, R. (2011). The impact of capital structure-choice on firm performance: Empirical investigation of listed companies in Colombo stock exchange, Srilanka. International Journal of Research in Commerce $\mathcal{E}^{\circ}$ Management, 2(4), 12-16.

Rahman, M. A., Sarker, M. S. I., \& Uddin, M. J. (2019). The impact of capital structure on the profitability of publicly traded manufacturing firms in Bangladesh. Applied Economics and Finance, 6(2), 1-5.Available at: https://doi.org/10.11114/aef.v6i2.3867.

Rajendran, K., \& Nimalthasan, P. (2013). Capital structure and its impact on firm performance: A study on Sri Lankan listed manufacturing companies. Kajananthan R, Nimalthasan P (2013) Capital structure and its impact on firm performance: A study on Sri Lankan listed manufacturing companies. Merit Research Journal of Business and Management, 1(2), 037-044.

Rosario, S., \& Chavali, K. (2019). Capital structure and its impact on profitability-a study of Indian hotel industry. International Journal of Business and Administration Research Review, 6(1), 67-72.

Sabin, D., \& Miras, H. (2015). Debt level and firm performance: A study on low-cap firms listed on the Kuala Lumpur stock exchange. International Journal of Accounting, Business and Management, 1(1), 1-17.

Saputra, T., Achsani, N. A., \& Anggraeni, L. (2015). The effect of capital structure on firm performance: Empirical evidence from the Indonesian financial industry. International Journal of Business and Management Invention, 4(8), 57-66.

Singh, N. P., \& Bagga, M. (2019). The effect of capital structure on profitability: An empirical panel data study. Jindal Journal of Business Research, 8(1), 65-77.

Uremadu, S., \& Onyekachi, O. (2018). The impact of capital structure on corporate performance in Nigeria: A quantitative study of consumer goods sector. Current Investigations in Agriculture and Current Research, 5(4), 650-658.Available at: https://doi.org/10.32474//ciacr.2018.05.000217.

Vătavu, S. (2015). The impact of capital structure on financial performance in Romanian listed companies. Procedia Economics and Finance, 32(15), 1314-1322.Available at: https://doi.org/10.1016/s2212-5671(15)01508-7.

Warrad, L., Al-Nimer, M., \& Al-Omari, R. (2016). The impact of liquidity on Jordanian banks profitability through return on assets. Research Journal of Finance and Accounting, 6(5), 26-29.

Wasfi, A. A., \& Haneen, H. H. (2016). The impact of capital structure on stock return; Empirical evidence from Amman stock exchange. International Journal of Business and Socal Science, 7(9), 183- 196. 